\title{
PECULIARITIES OF COMPLEX SENTENCES WITH OBJECT CLAUSES IN THE TEXTS OF MATHEMATICAL WORKS IN THE ENGLISH AND FRENCH LANGUAGES
}

\author{
PECULIARIDADES DE SENTENÇAS COMPLEXAS COM CLAUUSULAS DE OBJETO \\ NOS TEXTOS DE TRABALHOS MATEMATTICOS NAS LÍNGUAS INGLESA E \\ FRANCESA
}

\section{PECULIARIDADES DE LAS ORACIONES COMPLEJAS CON CLAUUSULAS OBJETO EN LOS TEXTOS DE OBRAS MATEMÁTICAS EN INGLÉS Y FRANCÉS}

\author{
Elena Borisovna VOLKOVA ${ }^{1}$ \\ Irina Alexandrovna REMENNIKOVA ${ }^{2}$ \\ Elena Alexeevna VECHERININA ${ }^{3}$
}

\begin{abstract}
The aim of the article is to study the basic structural and semantic qualities of two-component complex sentences with object clauses functioning in mathematical works in English and French. The works of outstanding modern mathematicians in the field of differential geometry and algebraic topology served as a material for the research. Using the technique of continuous sampling the authors extracted the sentences to be studied. The basic principles of communicative grammar, structural and semantic analysis, as well as statistical methods to process the extracted material, were applied. For the difficult material to be apprehended properly the language of mathematical works must obey some definite syntactical laws. Complex sentences with clear subordination of clauses favor, to a great extent, the logical consecutive statement of the mathematical text. Having a more complicated structure than simple sentences they are more evident in semantics, facilitating apprehension of the information being conveyed. Constructions with object clauses are highly productive among the complex sentences of the inseparable type. As a rule, it is the subordinate clause that contains somewhat novelty that promotes the advancement of the course of reasoning, whereas the main clause is assigned only an auxiliary part. The article covers such important features of the studied sentences as the position and construction of the main and subordinate clauses, their means of connection, morphological and semantic properties of the subordinating word etc. During the analysis of these structures in the two languages, some common features (for example, the absolute predominance of the preposition of the main clause), as well as considerable differences (for example, the absence of a conjunction in English) are revealed, which should be considered when working with the texts of mathematical works in these languages.
\end{abstract}

KEYWORDS: Complex sentence. Conjunction. Main clause. Object clause. Subordinating word.

\footnotetext{
${ }^{1}$ Moscow Aviation Institute, National Research University (MAI), Moscow - Russia. Associate Professor of the Institute of Foreign Languages and Candidate of Philological Sciences. ORCID: https://orcid.org/0000-00032267-0438. E-mail: lenka@mail.mipt.ru

2 Moscow Aviation Institute, National Research University (MAI), Moscow - Russia. ORCID: https://orcid.org/0000-0002-0517-876X. E-mail: remirina50@mail.ru

${ }^{3}$ Moscow Aviation Institute, National Research University (MAI), Moscow - Russia. Head of Chair of the Foreign Languages Institute. ORCID: https://orcid.org/0000-0002-9767-8613. E-mail: vealek@mail.ru
} 
RESUMO: $O$ objetivo do artigo é estudar as qualidades estruturais e semânticas básicas de sentenças complexas de dois componentes com orações objetais funcionando em trabalhos matemáticos em inglês e francês. Os trabalhos de destacados matemáticos modernos no campo da geometria diferencial e topologia algébrica serviram de material para a pesquisa. Utilizando a técnica de amostragem contínua os autores extraíram as sentenças a serem estudadas. Foram aplicados os princípios básicos da gramática comunicativa, análise estrutural e semântica, bem como métodos estatísticos de processamento do material extraido. Para que o material difícil seja apreendido adequadamente, a linguagem das obras matemáticas deve obedecer a algumas leis sintáticas definidas. Frases complexas com clara subordinação de orações favorecem, em grande parte, a afirmação lógica consecutiva do texto matemático. Tendo uma estrutura mais complicada do que frases simples, são mais evidentes na semântica, facilitando a apreensão da informação que está sendo veiculada. As construções com cláusulas de objeto são altamente produtivas entre as sentenças complexas do tipo inseparável. Via de regra, é a oração subordinada que contém algo novo que promove o avanço do curso de raciocínio, enquanto a oração principal é atribuída apenas a uma parte auxiliar. $O$ artigo cobre características importantes das frases estudadas como a posição e construção das orações principais e subordinadas, seus meios de conexão, propriedades morfológicas e semânticas da palavra subordinada etc. No decorrer da análise dessas estruturas nas duas línguas, algumas características comuns (por exemplo, a predominância absoluta da preposição da oração principal), bem como diferenças consideráveis (por exemplo, a ausência de uma conjunção em inglês) são reveladas e devem ser levadas em consideração no trabalho com os textos de trabalhos matemáticos nessas linguas.

PALAVRAS-CHAVE: Frase complexa. Conjunção. Cláusula principal. Cláusula de objeto. Palavra subordinadora.

RESUMEN: El objetivo del artículo es estudiar las cualidades estructurales y semánticas básicas de oraciones complejas de dos componentes con cláusulas de objeto que funcionan en trabajos matemáticos en inglés y francés. Los trabajos de destacados matemáticos modernos en el campo de la geometría diferencial y la topología algebraica sirvieron de material para la investigación. Utilizando la técnica del muestreo continuo los autores extrajeron las frases a estudiar. Se aplicaron los principios básicos de gramática comunicativa, análisis estructural y semántico, así como métodos estadísticos para procesar el material extraído. Para que el material dificil se aprehenda adecuadamente, el lenguaje de las obras matemáticas debe obedecer algunas leyes sintácticas definidas. Las oraciones complejas con clara subordinación de cláusulas favorecen en gran medida el enunciado lógico consecutivo del texto matemático. Al tener una estructura más complicada que las oraciones simples, son más evidentes en la semántica facilitando la aprehensión de la información que se transmite. Las construcciones con cláusulas de objeto son muy productivas entre las oraciones complejas del tipo inseparable. Como regla general, es la cláusula subordinada que contiene algo nuevo la que promueve el avance del curso del razonamiento, mientras que a la cláusula principal se le asigna solo una parte auxiliar. El artículo cubre características tan importantes de las oraciones estudiadas como la posición y construcción de las cláusulas principal y subordinada, sus medios de conexión, propiedades morfológicas y semánticas de la palabra subordinada, etc. En el curso del análisis de estas estructuras en las dos lenguas, se revelan algunas características comunes (por ejemplo, el predominio absoluto de la preposición de la cláusula principal), así como diferencias 
considerables (por ejemplo, la ausencia de una conjunción en inglés), que deben tenerse en cuenta al trabajar con el textos de trabajos matemáticos en estos idiomas.

PALABRAS CLAVE: Oración compleja. Conjunción. Cláusula principal. Clausula objeto. Palabra subordinada.

\section{Introduction}

The purpose of this article is to analyze the structural and semantic qualities of twocomponent complex sentences with object clauses, functioning in the scientific style of modern languages: English and French. The most important area for research is the substyle of the exact sciences, since it is in it that the original grammatical qualities of the studied structures are perfected. It is known that a mathematical text is characterized by brevity, consistency, and clarity of presentation of the content, whether it is a theorem or a description of the flow in a wind tunnel, the calculation of the amount of fuel consumed or periods of flares on the Sun. Assumptions, proofs and conclusions fit into the strict framework of syntactic structures, contributing to the adequate perception of the transmitted thought.

It is worth noting that French and English are analytical languages. This is expressed in the construction of the sentence. The members of the sentence are arranged strictly in direct order, i.e., in the first and second places there are the obligatory subject and predicate, respectively, then there can be a direct or indirect object, and only the place of the adverbial modifier can be varied. Scientific-style sentences can be replete with separate adverbial groups, if it is necessary to indicate the time, place, mode of action, i.e., details, without which the text will not have scientific and technical information (REMENNIKOVA, 2015). This distinction is of great importance when studying the syntactic features of the complex sentences with object clauses in these languages.

\section{Theoretical Basis}

The material for our research was the works of outstanding modern mathematicians in English and French: Cont (2018), Comte and Merle (2008), Demailly (2020), Donaldson (1982; 1983), Hitchin (1987), Lévy $(1980 ; 1990)$. Using the teqnique of continuous sampling we extracted about 1000 complex sentences with object clauses in each of the languages. The results obtained on the similarities and differences of these syntactic structures can be useful 
in translating and writing scientific and technical texts. In this article, for brevity, we will provide data for the two languages in the following way: English / French.

Our research is based on the structural-semantic approach developed by Pospelov (1959), Maksimov (1969) among others. They divide all complex sentences into two groups: of inseparable type and separable one. In the complex sentences of the first type there is a close interrelation between the subordinate clause and one member of the main clause whereas in the second group the subordinate clause is interrelated with the whole main part.

It is known that complex sentences with object clauses make up the most productive model among the constructions of the inseparable type in the scientific style "since they always introduce new information about the object" (VOLKOVA, 2016, p. 28). The structural and semantic qualities of the complex sentences of inseparable type in Russian mathematical texts were the subject of a detailed consideration in the works of Volkova $(2015 ; 2016)$. It should be said that a widespread use of infinitive expressions in the texts of mathematical works in English and French reduces the productivity of the complex sentences with object clauses. Simple sentences with infinitive constructions are synonymous with them. For example: Two functions are said to Poisson-commute (HITCHIN, 1987) (Compare: It is said that two functions Poisson-commute). Supposons au contraire que pour mesurer la distance de deux traits de repère, on déplace à chaque lecture la régle graduée (LÉVY, 1980). (Compare: Supposons au contraire qu 'on puisse mesurer la distance de deux traits de repère, ayant déplacé à chaque lecture la régle graduée). Infinitive constructions are compact and laconic, but a complex sentence with a clear hierarchical structure is more convenient for proper perception of complex material.

\section{Methodology}

In our research we used the above mentioned structural and semantic approach as the fundamental method along with the basic principles of communicative grammar. To identify the implicit differences in the structure and semantics of the complex sentences under investigation the transformational and textological analyses were applied. We also used linguistic description based on the principle of induction and the statistical method to process the material and determine the frequency of the investigated structures. To collect the material, we applied the technique of continuous sampling. 


\section{Results and Discussions}

The most important structural characteristic of complex sentences with object clauses is the preposition of the main part in a great majority of the studied constructions. Only in few cases $(4.6 \% / 3.8 \%)$ the subordinate part occupies an interpositive position in relation to the main clause, shifting the semantic focus to the remaining part of the main clause. Omitting the condition that $\psi$ respects orientations, we get the notion of weak morphism (MANIN, 2002). Suposons que l'origine de $R^{n}$ soit dans $X$, et notons $X 0$ le germe à l'origine définissant $X$ (COMTE; MERLE, 2008). In all other sentences of our sample, the role of the main clause is secondary: it is small in volume, reduced in content, and has a bright modal character. Its entire purpose is to serve the subordinate clause which contains the informative core of the statement. The morphological characteristics of subordinating words are very diverse. First, this is the position with the verb $(59.8 \%$ / 63.8\%). As a rule, this subordinating word is used in the present tense of an imperfect form, which is associated with an abstract, timeless nature of the narrative adopted in the texts of mathematical works. In the studied material, both in English and in French, the verb in the active voice was used 7 / 5 times more often than in the passive one. In 1/3 of the cases in English and French, the main part represents the verb in the imperative: assume, remind, suppose, note / rappelons, supposons, considérons. Finally note that the sheaf map (5.4) gives rise to an exact sequence of sheaves (HITCHIN, 1987). Suppose A sp $(m C)$ has distinct eigenvalues $\lambda i$ with eigenvectors vi on C2m (HITCHIN, 1987). Rappelons que pour tout z $2 C$, $\exp (z)=X n \ldots O$ (Cont: 2018). Supposons que $f$ est $k$ lipschitzienne en $y$. Considérons le problème suivant: $y^{\prime}=f(t, y), y\left(t_{o}\right)=y_{o}$ (DEMAILLY, 2020).

It is interesting to note that in English texts of mathematical works, only in such sentences the main and object clauses are connected asyndetically in single cases. The conjunction is often omitted in complex sentences with object clauses in the common-literary language, but the scientific style is characterized by "full structure and strict normativity of the regular design of syntactic elements" (KOZHINA et al., 2008, p. 211). Indeed, in the rest complex sentences in English the main clause necessarily contains both the subject (often formal it or indefinite personal one) and the predicate, since they "invariably enter the structural-semantic minimum of the English sentence" (IVANOVA et al., 1982, p. 74).

As a rule, in a French mathematical text, when transmitting information, there are no elements of expression of a subjective assessment, the use of pronoun and tense verb forms is limited, there is a predominant use of impersonal and indefinite personal structures (indefinite 
personal pronoun on, il-neutral), passive verb form, intensifying, limiting, infinitive, adverbial and participial phrases, while in oral communication in French, the forms of the verb present, simple future and past tense of the 1 st person singular indicative mood, as well as the imperative mood (l'Impératif) are often used (REMENNIKOVA, 2015). A mathematical text is a kind of a mathematical discourse. The author communicates with the reader, and in his person - with the mathematical community. In this case, in French, for the structure of a complex sentence in its main part, it is logical to use a verb in the first person of the plural (Présent / Future / Passé de l'Indicatif). Nous dirons (le Futur simple de l'Indicatif) que Dx $(P)$ est l'image de X associée à P (COMTE; MERLE, 2008).

This is followed by a group of sentences $(11.3 \% / 15.28 \%)$ with a compound verb predicate in the main part: a word of modal meaning + infinitive: easy to prove, interesting to note, can check, etc. Anticipating here preposition 18 we can say that the subset $K \in M$. (DONALDSON, 1983). Il nous suffit de remarquer ici que $U<t$ pour être assuré qu'on diminue le poids des grandes valeurs de y en revenant de la formule à la formule (LÉVY, 1990). A special, indirect manifestation of the author's opinion is observed here.

In our material the words of modal meaning as the subordinating words of the main clause are frequent in logical reasoning $(6.7 \%$ / 6.9\%) They are: it is evident, it is clear, it is (well -) known / il est évident, il est clair, il est connu. It is clear that $J(A(s, t))<J i$ (DONALDSON, 1982). Il est évident que la loi limite est une loi de Lévy, et non une loi normale (CONT, 2018). The introductory nature of the main part in English and French complex sentences is not so striking due to the full-structured construction of the main part (formal subject + linking verb + adjective or participle), however, these constructions are also quite stereotyped in the texts of mathematical works.

A certain group of verbal nouns is steadily used as subordinating words in English (5.2\%) (and not typical of French). While retaining verb government, they require a subordinate clause with an object meaning after themselves: fact, assumption, conclusion, consequence. Such words indicate a phenomenon that is revealed in the subordinate clause. These nouns usually lack semantics. The fact that $V$ is of odd degree only changes the isomorphism with the Prym variety (HITCHIN, 1987). Additional explicit attributive semantics is evidently observed in such sentences.

Much more frequent (13.4\%) in the English language are "predicate" complex sentences: the explicable word is paired with a compound predicate, where after the linking verb and the conjunction that follows an expanded nominal predicate, expressed by a subordinate clause. The advantage of this construction of $V$ is that it depends only on the 
bundle $V i *$, the kernel of $g$ (HITCHIN, 1987). Here the semantic load of the main part is minimal too.

The overwhelming majority of the complex sentences with object clauses in the material under study uses the conjunction that / que $(95.2 \% / 95.3 \%)$. It combines subordinating words of various morphology with the semantics of being, identification, detection, mental activity, information transfer, and mathematical terms. The unreal modality of the object in the Romano-Germanic languages is achieved by using the subjunctive mood in the subordinate clause, attached by the conjunction that / que and / or by the semantics of the explicated word. The subordinating word in the main clause has a modal meaning: it is necessary, it is sufficient, it is important / il est nécessaire, il est important, il est possible, il est utile or semantics of the requirement: to claim, requirement / demander, exiger. It is important that projections could be produced from such a set up (MANIN, 2002). Then we claim that $B(M, n, k)$ is simply connected for $n>3$ (DONALDSON, 1983). Il est important que dans la moyenne des quatre pentes, un poids plus grand soit donné aux pentes au point milieu (DEMAILLY, 2020). In all the examples, it can be seen that the entire structure acquires additional purpose semantics.

In the material under study, a small part $(4.8 \% / 7.6 \%)$ is made up of complex sentences with object clauses of relative subordination connected by conjunctions if, whether / soit. In constructions with the listed conjunctions, the object expresses not just a message as such, but some uncertainty, providing options for a possible two-fold solution. An alternative solution to the question is either implied as the opposite of this statement or is introduced explicitly by modification or / soit ... soit. Subordinating words with the meaning of knowledge (ignorance), misunderstanding, reflection contribute to the creation of interrogative semantics. It is not yet clear whether the methods which we use here can be extended to the intermediate cases (MANIN, 2002). On peut se demander s'il ne suffirait pas que $m 1, m 2, \ldots$ mn, soient inférieures à ćM (LÉVY, 1980). On en déduit que Soit $m$ 1, soient $X 1 ; \ldots ; X n$ des variables aléatoires réelles indépendantes (CONT, 2018).

Interrogative semantics can be created in complex sentences with object clauses using various relative pronouns or adverbs when, where, how, why / où, comment etc. These interrogative words organize the form of an indirect question (in the subordinate clause), at the same time satisfying the need of the explicated word for object extension. To do this we consider how V1 arose and dualize the exact sequence (5.18) (HITCHIN, 1987). C'est le cas où $\alpha=1$ conduit à une loi de Cauchy (LÉVY, 1990). In all indirectly interrogative sentences 
additional semantics is observed (for example, in the first case - the manner), which is introduced by one or another relative pronoun or adverb.

\section{Conclusions}

Thus, from the above examples, it can be seen that in mathematical works in the complex sentences with object clauses the main part is largely of a formula nature, performs service, organizing functions, while the subordinate part contains the main meaning of the sentence. The use of cliches, the stereotypical nature of scientific speech is justified by the tasks that arise in this area of the scientific style: to convey a thought as accurately, concisely and unambiguously as possible.

The style of presentation of mathematical texts has its own distinct features in the studied languages. It is capacious, clear, laconic, replete with terms and specific phraseological phrases, mathematical symbols, formulas and equations that complicate the visual perception of the content of the text when translated from one language to another. In a comparative analysis of the structure and semantics of complex sentences with object clauses in English and in French one can identify both their similarities and significant differences that must be considered when translating mathematical works.

\section{REFERENCES}

COMTE, G.; MERLE, M. Equisingularité réelle II. Annales scientifiques de L'École normale supérieure, v. 41, n. 2, p. 221-269, 2008.

CONT, R. La statistique face aux événements rares ou extremes. Dossier pour la Science, v. 98, 2018. Available: http://pourlascience.fr/sd/mathematiques/evenements-rares-prévoirlimprobable-10032.php. Access: 10 Jul. 2020.

DEMAILLY, J. P. Analyse numérique et équations différentielles. Méthodes de Runge-Kutta. Pour la Science, v. 389, 2020. Available: http://fr.wikipedia.org/wiki/Méthodes_de RungeKutta. Access: 10 Jul. 2020.

DONALDSON, S. K. A new form of a theorem of Narasimhan and Seshadri. Differential geometry, v. 18, p. 269-277, 1982.

DONALDSON, S. K. An application of gauge theory to four dimensional topology.

Differential geometry, v. 18, p. 279-318, 1983.

HITCHIN, N. Stable bundles and integrable systems. Duke mathematical journal, v. 54, n. 1, p. 59-114, 1987. 
IVANOVA, I. P. et al. Theoretical grammar of modern english. Moscow: Vysshaya shkola, 1982.

KOZHINA, M. N. et al. The stylistics of the russian language. Moscow: Flinta: Nauka, 2008.

LÉVY, P. Le théorème fondamental de la théorie des erreurs. Annales de l'Institut Henri Poincaré, v. 1, n. 2, p. 163-177, 1980.

LÉVY, P. Sur certains processus stochastiques homogènes. Composito Mathematica, v. 7, p. 283-339, 1990.

MAKSIMOV, L. Y. Thoughts about modern russian language. Moscow: Nauka, 1969.

MANIN, J. I. Real multiplication and noncommutative geometry. Bonn: Max-PlanckInstitute für Mathematik, 2002.

POSPELOV, N. S. Complex sentence and its structural types. Issues of linguistics, v. 2, p. 21-27, 1959.

REMENNIKOVA, I. A. Syntactic analysis of a sentence in teaching reading and translating authentic technical texts in French (aerospace topics). In: The role of a modern university in the technical and personnel modernization of the russian economy. Kostroma: Kostroma State Technological University, 2015. p. 90-93.

VOLKOVA, E. B. Complex sentences of an inseparable type in the scientific style of the russian language (based on the works of a mathematical cycle): abstract dis. Candidate of philological sciences: 10.02.01. Vologda state university, Vologda, 2016.

VOLKOVA, E. B. The role of object clauses in multicomponent complex sentences (based on works of a mathematical cycle). Bulletin of the Pyatigorsk State Linguistic University, v. 3, p. 30-37, 2015.

\section{How to reference this article}

VOLKOVA, E. B; REMENNIKOVA, I. A.; VECHERININA, E. A. Peculiarities of complex sentences with object clauses in the texts of mathematical works in the english and french languages. Rev. EntreLínguas, Araraquara, v. 7, n. esp. 2, e021021, 2021. e-ISSN: 24473529. DOI: https://doi.org/10.29051/el.v7iesp.2.15147

Submitted: 05/01/2021

Required revisions: $26 / 02 / 2021$

Approved: 24/03/2021

Published: 01/06/2021 